\title{
Characterization of Fat Particles in Plasma of Hyperlipemic Subjects Maintained on Fat-free High-Carbohydrate Diets *
}

\author{
Edwin L. Bierman, Daniel Porte, Jr., $\dagger$ David D. O'Hara $\$$ Maurice \\ SchWartz, $\S$ and Francis C. WoOd, JR. \\ (From the Department of Medicine, University of Washington School of Medicine, and the \\ Veterans Administration Hospital, Seattle, Wash.)
}

Lipemia in man is characterized by the presence of fat particles circulating in plasma (1). These fat particles are the largest of the plasma lipid-protein aggregates, contain predominately triglyceride, and when present in sufficient concentration, cause plasma to appear turbid or lactescent (2). The persistence of lipemic plasma in the postabsorptive state is considered to be abnormal.

In the absence of an underlying major disease (notably insulin-dependent diabetes, pancreatitis, or nephrosis) the cause of hyperlipemia is unknown (3). Ahrens and colleagues (4-6) have described two forms of primary hyperlipemia, separable in part by their response to low-fat, high-carbohydrate diets. In "fat-induced lipemia," plasma clears as a result of dietary fat reduction, whereas in "carbohydrate-induced lipemia" grossly visible lipemia is maintained. These divergent dietary responses suggest that the fat particles accumulating in plasma of hyperlipemic patients may have different properties. It has recently been shown that the plasma fat particles of normal subjects following high-fat meals are heterogeneous (7). Even though they all readily float in saline $(\mathrm{D}<1.006)$, they can be fractionated into distinct classes by zone elec-

* Submitted for publication August 17, 1964 ; accepted October 26, 1964.

Supported in part by U. S. Public Health Service grants AM 06670 and AM 02456. A portion of this work was conducted through the Clinical Research Center Facility of the University of Washington (National Institutes of Health grant FR-37).

$\dagger$ Advanced research fellow, American Heart Association.

$\ddagger$ Postdoctoral research fellow, National Institutes of Health.

$\S$ Present address: Department of Medicine, Chicago Medical School and Mount Sinai Hospital, Chicago, Ill. trophoresis on a nonadsorbing medium, such as granular starch, and by differential flocculation in polyvinylpyrrolidone (PVP) gradients (8). "Primary" particles migrate in the alpha 2 globulin region, flocculate at the top of the PVP solution, and appear to be identical with particles in lymph (chylomicrons). On the other hand, "secondary" particles migrate in the beta globulin region, flocculate at the bottom of the PVP solution, and possibly originate in the liver. Both types of particle produced in normals are rich in triglyceride (85 to $90 \%$ of the particle mass) and are estimated to be larger than 75 to 100 $\mathrm{m} \mu$ in diameter $\left(\mathrm{S}_{\mathrm{f}}>400\right)$.

An index to the nature of certain forms of hyperlipemia might be obtained from a characterization of plasma particulate fat by these fractionation techniques. Swahn found that a variety of lipemic plasma samples, analyzed by free electrophoresis, contained two turbid peaks (9). Similar results were obtained by Carlson and O1hagen, using starch column electrophoresis, in plasma from a patient with "essential" hyperlipemia (10). Presumably, these samples were obtained from patients whose diets contained fat. In the present study, particulate fat in plasma of hyperlipemic subjects has been characterized during prolonged periods of ingestion of fat-free diets. Patients who remain grossly hyperlipemic under these circumstances were found to have a homogeneous group of plasma fat particles distinct from those appearing after fat ingestion.

\section{Methods}

Clinical procedures. Patients with grossly turbid plasma in the postabsorptive state and without manifest renal, hepatic, or thyroid disease were studied on a metabolic ward. Each patient received sufficient calories to 
maintain body weight. Weight variations did not exceed $\pm 1 \mathrm{~kg}$. When initial observations had been made after patients were on a basal diet ( $40 \%$ fat calories, $45 \%$ carbohydrate calories, $15 \%$ protein calories) for at least 1 week, they received a diet consisting of $85 \%$ carbohydrate calories, $15 \%$ protein calories, and virtually no fat. The diet was either totally liquid or was modified by the addition of rice, matzos, fruit, sucrose, and fat-free vegetables. The source of carbohydrate in the liquid formula was either dextrose or a mixture of dextrins and maltose (Dextri-maltose).1

Intravenous glucose tolerance tests were performed using $0.5 \mathrm{~g}$ per $\mathrm{kg}$ rapid ( $<5$-minute) glucose injections during periods of adequate carbohydrate intake. Fractional removal rates $(k)$ were determined after calculation of the slope (b) of the straight line formed by the plot of logarithms of glucose values [glucose oxidase method (11) or autoanalyzer (12)] from 20 to $60 \mathrm{~min}$ utes by the formula $k=2.3 \mathrm{~b}$ and expressed as per cent per minute. Two-hour postprandial glucose levels were obtained after the ingestion of $100 \mathrm{~g}$ glucose. Postheparin plasma lipoprotein lipase assays were performed by the method of Fredrickson, Ono, and Davis (13) during periods of normal or high fat intake. Plasma triglyceride levels were determined by a modification of the method of Carlson previously described (14), in some instances further modified by substitution of higher boiling isopropyl ether for ethyl ether in the batch elution step.

When plasma triglyceride levels had stabilized on the fat-free, high carbohydrate diet (usually 2 to 3 weeks), samples of venous blood for fat particle characterization were obtained after an overnight fast and collected in tubes containing ethylenediamine tetraacetic acid (EDTA).

At the end of this fat-free, high-carbohydrate feeding period, eight patients received a fat load of corn oil (2 to $3 \mathrm{~g}$ per $\mathrm{kg}$ ) blended in skim milk (except patient Sa, who received whole milk). Venous blood samples collected in EDTA were obtained periodically for the next 24 to 48 hours while fat-free feeding was continued.

Laboratory methods. Zone electrophoresis on starch granule blocks was performed at 15 to $20^{\circ} \mathrm{C}$ by the method of Kunkel and Trautman (15) under conditions previously described (7). Electrophoresis was continued for sufficient time for albumin to migrate 6 to 8 inches from the origin toward the anode (18 to 24 hours). Starch segments $1 \mathrm{~cm}$ or $\frac{1}{2}$ inch wide were cut and eluted with $0.9 \% \mathrm{NaCl}$ by stirring in a Vortex mixer (7). Samples of each fraction were removed for protein determination (16) and nephelometric measurement (Coleman model 14; adapted for nephelometry). Migration distance of each turbid peak was determined by triangulation and expressed relative to the migration distance of albumin (1.0). Two to five such determinations of relative migration were made from samples obtained on different days during a single fat-free, high-carbohydrate

1 Mead Johnson, Evansville, Ind. period for each of several subjects. Calculation of the precision of replicate analysis (17) yielded a coefficient of variation of $11 \%$.

There appeared to be several factors affecting particle mobility, in addition to $\mathrm{pH}$ and ionic strength of the buffer. Exposure of plasma to refrigerator temperatures produced visible creaming in some samples that was associated with adherence of particles to the starch at the origin. A similar effect was noted with prolonged storage. Therefore, electrophoresis was performed within 24 hours after collection. Samples were kept at room temperature and warmed briefly to $37^{\circ} \mathrm{C}$ before application to the block. There was some variation among different lots of potato starch. The most consistent results were obtained with the coarsest starch available. Fatty acids, liberated by in vitro lipolysis from lipemic samples, theoretically could have affected particle mobility (18). Prolonged incubation of lipemic plasma at $37^{\circ} \mathrm{C}$, which produced a fivefold increase in titratable free fatty acids, resulted in the migration of all the liberated fatty acids in the albumin fraction, and particle mobility was not altered.

Fat particles $\left(S_{\ell}>400\right)$ were isolated for analysis from pooled turbid electrophoretic fractions by centrifugation in a Spinco SW 39 swinging bucket rotor approximately $3 \times 10^{\circ} \mathrm{g} \times$ minutes at 20 to $25^{\circ} \mathrm{C}$ in the model L2 ultracentrifuge. The packed surface band of fat particles was removed in a minimal volume by careful suction, resuspended, a layer of $0.9 \% \mathrm{NaCl}$ added, and spun a second time under the same conditions. The particulate fat was then extracted in chloroform:methanol (2:1, vol: vol), and the extracts were washed once with $\frac{1}{5}$ vol of $0.9 \% \mathrm{NaCl}$ containing $0.1 \%$ EDTA. The chloroform layer was evaporated to dryness, transferred to $10-\mathrm{ml}$ volumetric flasks, and made up to volume with chloroform. The extracts were kept at $-10^{\circ} \mathrm{C}$ until analyses were performed. Analyses of fat particles isolated after a third centrifugation through saline, when compared to those obtained after the second centrifugation, yielded virtually identical composition but substantially reduced recovery; hence two spins were selected for routine analysis.

Portions of the particulate fat extract were analyzed for total sterol by the ferrous sulfate method (19), for esterified sterol after thin-layer silicic acid fractionation (20), for lipid phosphorus by the Bartlett method (21), and for total fatty acids by the single extraction and titration procedure of Dole and Meinertz (22) after saponification with $0.5 \mathrm{~N} \mathrm{KOH}$ in $95 \%$ ethanol for 2 hours at $80^{\circ} \mathrm{C}$. The per cent composition by weight of each major lipid class was calculated after the following corrections were made: 1) Total sterol $\times 1.5=$ total cholesterol (TC) (assuming $\frac{2}{3}$ of total sterol is esterified, and the average mol wt of fatty acid (FA) esters is 280). 2) Lipid $P \times 25=$ phospholipid (PL). 3) Total fatty acids (TFA, in microequivalents) $\times 280=$ total fatty acids (micrograms).

Triglycerides were calculated as follows by assuming FA represents by weight, $95 \%$ of triglyceride, $72 \%$ of 
TABLE I

Patient data: glucose tolerance, postheparin lipolytic activity, and triglyceride levels in plasma

\begin{tabular}{|c|c|c|c|c|c|c|c|c|c|}
\hline \multirow{2}{*}{ - } & \multirow[b]{2}{*}{ Patient } & \multirow[b]{2}{*}{ Age } & \multirow[b]{2}{*}{ Sex } & \multirow{2}{*}{$\begin{array}{c}\text { Fasting } \\
\text { blood } \\
\text { glucose }\end{array}$} & \multirow{2}{*}{$\begin{array}{c}\text { 2-hr } \\
\text { post- } \\
\text { prandial } \\
\text { glucose }\end{array}$} & \multirow{2}{*}{$\begin{array}{c}\text { iv glucose } \\
\text { tolerance } \\
\mathbf{k}^{*}\end{array}$} & \multirow[b]{2}{*}{ LPL† } & \multicolumn{2}{|c|}{ Plasma triglycerideł } \\
\hline & & & & & & & & $\begin{array}{c}\text { Basal } \\
\text { diet }\end{array}$ & $\begin{array}{c}\text { Fat-free } \\
\text { diet }\end{array}$ \\
\hline \multirow{16}{*}{. } & & \multirow{16}{*}{$\begin{array}{l}42 \\
50 \\
45 \\
41 \\
55 \\
65 \\
53 \\
34 \\
38 \\
43 \\
55 \\
48 \\
55 \\
50 \\
38\end{array}$} & \multirow{16}{*}{$\begin{array}{l}\mathbf{F} \\
\mathbf{F} \\
\mathbf{M} \\
\mathbf{M} \\
\mathbf{M} \\
\mathbf{F} \\
\mathbf{M} \\
\mathbf{M} \\
\mathbf{M} \\
\mathbf{M} \\
\mathbf{M} \\
\mathbf{M} \\
\mathbf{M} \\
\mathbf{M} \\
\mathbf{M}\end{array}$} & \multirow{16}{*}{$\begin{array}{c}m g / 100 m l \\
107 \\
129 \\
85 \\
61 \\
99 \\
88 \\
82 \\
86 \\
85 \\
85 \\
80 \\
67 \\
119 \\
91 \\
78\end{array}$} & $m g / 100 \mathrm{ml}$ & \multirow[t]{2}{*}{$\% \min$} & $\mu E q / m l / m i n$ & \multicolumn{2}{|c|}{$m g / 100 m l$} \\
\hline & $\mathrm{Ok}$ & & & & & & 0.47 & 4.300 & 3.720 \\
\hline & Ko & & & & 247 & & 0.33 & 2,810 & 3,2008 \\
\hline & $\mathrm{Sa}$ & & & & 145 & 0.81 & 0.48 & 1,420 & $2,730^{\circ}$ \\
\hline & Mc & & & & 100 & & 0.33 & 1,430 & 2,4008 \\
\hline & $\mathrm{Se}$ & & & & 200 & 1.16 & 0.27 & 1,720 & 2,400 \\
\hline & $\mathbf{R a}$ & & & & 145 & 1.45 & 0.22 & 1,590 & 2,200 \\
\hline & $\mathrm{Gi}$ & & & & 150 & & & $550 \|$ & 1,700 \\
\hline & $\mathrm{Ja}$ & & & & 135 & 0.69 & 0.39 & $2,870^{\prime \prime}$ & 810 \\
\hline & $\mathrm{Pr}$ & & & & 132 & & & $400 \|$ & 800 \\
\hline & $\mathrm{Di}$ & & & & 150 & 1.17 & 0.28 & 2,000 & 800 \\
\hline & Pea & & & & 165 & 0.64 & 0.40 & 575 & 775 \\
\hline & Pet & & & & 130 & 1.07 & 0.43 & 365 & 730 \\
\hline & $\mathrm{Al}$ & & & & 250 & 1.05 & & 525 ه & 525 \\
\hline & $\mathrm{Ha}$ & & & & 142 & & 0.45 & 300 & 370 \\
\hline & & & & & 100 & & & 180 & 290 \\
\hline & Mean & & & & & 1.01 & 0.37 & & \\
\hline & SD & & & & & 0.27 & 0.09 & & \\
\hline
\end{tabular}

${ }^{*} \mathbf{k}=$ fractional removal rate.

† Lipoprotein lipase activity on regular or high-fat diets.

$¥$ Mean values after steady levels reached in each dietary period.

8 From Knittle and Ahrens (6).

High-fat diet.

If Ad libitum diet.

$\mathrm{PL}$, and $33 \%$ of $\mathrm{TC}$, respectively: $\mathrm{TG}=(\mathrm{TFA}-0.72$ $\mathrm{PL}-0.33 \mathrm{TC}) / 0.95$.

When sufficient material was available, particulate fat extracts were analyzed for triglyceride by the above total fatty acid method and by the direct glycerol method. Both methods agreed closely (coefficient of variation $=1.5 \%$ for nine pairs).

Plasma obtained at the end of the fat-free feeding period, before and after the ingestion of corn oil, was' analyzed for turbidity, and particulate fat fractions were separated by both starch block electrophoresis and PVP flocculation (8). Columns of 3\% PVP were used rather than 0 to $5 \%$ gradients, because of relative ease of preparation and the demonstration that both methods provide similar separations (23). Triglyceride fatty acid (TGFA) composition of the isolated fat particles was determined by methods previously described (7), which include thin-layer silicic acid chromatography for separation of triglycerides from chloroform-methanol extracts and gas-liquid chromatography for analysis of TGFA methyl esters. Gas-liquid chromatography was performed on 4 or 6-foot ethylene glycol succinate polyester columns at $175^{\circ} \mathrm{C}$ with an argon ionization detector containing an $\mathrm{Sr}^{20}$ source (either Barber-Colman series 5000 or Pye-Argon). Relative mass distributions were calculated from the major peaks $(14: 0,16: 0,16: 1,18: 0$, $18: 1,18: 2)^{2}$ by triangulation. Qualitative results with

2 Shorthand designation for fatty acids, identified by chain length and number of double bonds (24).
NIH fatty acid standards $A$ to $D$ agreed with the stated composition data with a relative error of less than $15 \%$ for major components and less than $16 \%$ for minor components. Eleven determinations with the $D$ standard gave a reproducibility ranging from \pm 1.8 to $4.9 \%$ for all components. Samples of buttock adipose tissue (25) and the corn oil mixture were processed in a similar manner.

\section{Results}

All patients in this group had demonstrable abnormalities of carbohydrate tolerance (Table I). Three (Ok, Ko, Al) had clinically evident, mild, adult-onset diabetes with elevated fasting blood glucose levels and occasional glucosuria. Of the other 12 patients, all had normal fasting blood glucose levels, but elevated levels ( $>100$ $\mathrm{mg}$ per $100 \mathrm{ml}$ ) 2 hours after a carbohydrate load. The average fractional removal rate $(k)$ of intravenous glucose loads, $1.01 \pm 0.27 \%$ per minute, was intermediate between results in normals $(1.74 \pm 0.85, n=19)$ and in a series of nonhyperlipemic mild adult diabetics with normal fasting blood glucose $(0.74 \pm 0.26, \mathrm{n}=25)$ (26). Plasma postheparin lipolytic activity was within 


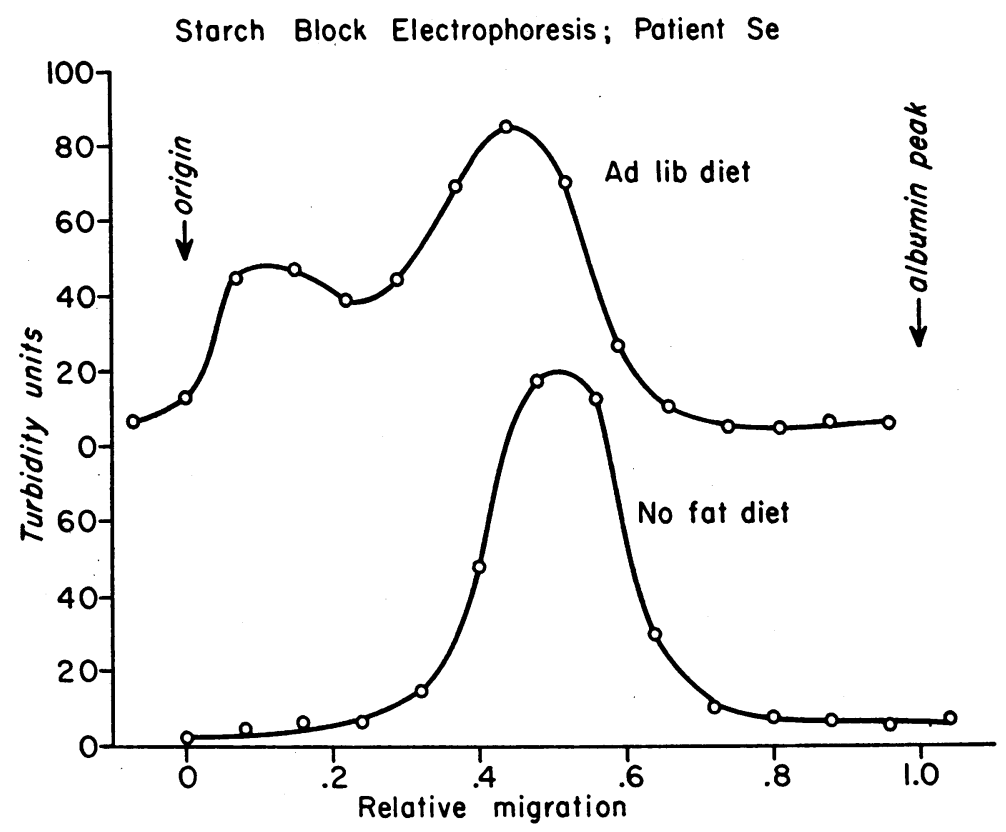

Fig. 1. Starch block electrophoresis of plasma of patient Se on an ad LIBITUM DIET AND ON A FAT-FREE DIET.

TABLE II

Electrophoretic mobility and lipid composition of particulate fat in plasma ("fat-free" diet)

\begin{tabular}{|c|c|c|c|c|c|c|c|}
\hline \multirow[b]{2}{*}{ Patient } & \multicolumn{3}{|c|}{ Plasma lipids* } & \multirow[b]{2}{*}{ Migration $†$} & \multicolumn{3}{|c|}{ Lipid composition } \\
\hline & Triglyceride & Cholesterol & Phospholipid & & $\begin{array}{c}\text { Total } \\
\text { cholesterol }\end{array}$ & Phospholipid & $\begin{array}{l}\text { Trigly- } \\
\text { ceride }\end{array}$ \\
\hline \multicolumn{5}{|c|}{$m g / 100 m l$} & \multicolumn{3}{|c|}{$\%$ by wt } \\
\hline Ok & 4,356 & 1,020 & 1,183 & 0.59 & 20 & 6 & 74 \\
\hline Ko & 2,361 & 556 & 705 & 0.57 & 18 & 13 & 69 \\
\hline $\mathrm{Sa}$ & 2,186 & 410 & & 0.47 & 15 & 10 & 75 \\
\hline Mc & $2,100-2,800$ & $840-1,000$ & $710-810$ & 0.49 & 26 & 4 & 69 \\
\hline $\mathrm{Se}$ & 2,450 & 411 & & 0.51 & 15 & 11 & 74 \\
\hline $\mathbf{R a}$ & 662 & 301 & & 0.53 & 18 & 10 & 72 \\
\hline Gi & 1,600 & 320 & 500 & 0.56 & 12 & 10 & 78 \\
\hline $\mathrm{Ja}$ & $860-980$ & $321-400$ & $367-418$ & 0.33 & 21 & 13 & 66 \\
\hline $\mathrm{Pr}$ & 800 & 270 & 335 & 0.58 & 20 & 9 & 71 \\
\hline $\mathrm{Di}$ & $742-811$ & $261-320$ & $325-358$ & 0.49 & 24 & 11 & 65 \\
\hline Pea & 990 & 285 & & 0.50 & 19 & 12 & 69 \\
\hline Pet & 553 & 283 & 345 & 0.50 & 26 & 14 & 60 \\
\hline Al & 500 & 226 & 273 & 0.64 & 15 & 13 & 72 \\
\hline $\mathrm{Ha}$ & 360 & 117 & 165 & 0.45 & 25 & 13 & 62 \\
\hline Bo & 304 & 204 & 260 & 0.47 & 19 & 9 & 71 \\
\hline Mean & & & : & 0.51 & 20 & 10 & 70 \\
\hline SD & & & & 0.07 & 4 & 3 & 5 \\
\hline \multicolumn{8}{|c|}{ Normal subjects } \\
\hline \multirow{2}{*}{\multicolumn{4}{|c|}{$\begin{array}{l}\text { Primary particles, mean } \pm S D(n) \\
\text { Secondary particles, mean } \pm S D(n)\end{array}$}} & $0.60 \pm 0.10(21)$ & $8 \pm 3(7)$ & $6 \pm 4(7)$ & 86 \\
\hline & & & & $0.23 \pm 0.08(23)$ & $7 \pm 2(8)$ & $3 \pm 1(8)$ & 90 \\
\hline
\end{tabular}

* At time of particle analysis.

$\dagger$ Migration of turbid peak relative to albumin peak (albumin $=1.00$ ). 
TABLE III

TGFA* compositon of hyperlipemic particles (fat-free diet) and adipose tissue

\begin{tabular}{|c|c|c|c|c|c|c|c|c|c|c|c|c|}
\hline \multirow[b]{2}{*}{ Patient } & \multicolumn{6}{|c|}{ Hyperlipemic particles } & \multicolumn{6}{|c|}{ Adipose tissue } \\
\hline & $14: 0$ & $16: 0$ & $16: 1$ & $18: 0$ & $18: 1$ & $18: 2$ & $14: 0$ & $16: 0$ & $16: 1$ & $18: 0$ & $18: 1$ & $18: 2$ \\
\hline $\begin{array}{l}\mathrm{Ok} \\
\mathrm{Sa} \\
\mathrm{Se} \\
\mathrm{Ra} \\
\mathrm{Di} \\
\mathrm{Pea} \\
\mathrm{Al} \\
\mathrm{Ja}\end{array}$ & $\begin{array}{l}2.6 \\
3.0 \\
7.8 \\
2.8 \\
2.6 \\
5.0 \\
2.9 \\
3.7\end{array}$ & $\begin{array}{l}42.2 \\
34.6 \\
43.1 \\
30.5 \\
43.2 \\
32.9 \\
44.7 \\
37.4\end{array}$ & $\begin{array}{r}9.1 \\
11.1 \\
8.7 \\
8.2 \\
5.5 \\
6.6 \\
6.6 \\
4.2\end{array}$ & $\begin{array}{r}3.0 \\
7.9 \\
5.2 \\
3.9 \\
6.5 \\
10.0 \\
4.1 \\
8.6\end{array}$ & $\begin{array}{l}35.0 \\
37.7 \\
37.1 \\
43.2 \\
33.0 \\
41.0 \\
33.8 \\
38.1\end{array}$ & $\begin{array}{r}8.1 \\
5.7 \\
3.1 \\
11.5 \\
9.1 \\
4.4 \\
7.9 \\
8.2\end{array}$ & $\begin{array}{l}2.6 \\
2.0 \\
1.6 \\
2.7 \\
5.2 \\
2.6 \\
2.3\end{array}$ & $\begin{array}{l}26.8 \\
22.8 \\
20.4 \\
23.3 \\
27.6 \\
28.6 \\
28.0\end{array}$ & $\begin{array}{l}8.7 \\
8.7 \\
6.2 \\
6.0 \\
9.0 \\
6.2 \\
6.7\end{array}$ & $\begin{array}{l}3.5 \\
2.6 \\
3.2 \\
4.1 \\
3.7 \\
2.9 \\
3.6\end{array}$ & $\begin{array}{l}47.9 \\
\\
51.5 \\
47.1 \\
46.5 \\
43.7 \\
50.0 \\
51.1\end{array}$ & $\begin{array}{r}10.6 \\
10.9 \\
20.0 \\
16.9 \\
9.2 \\
10.0 \\
8.3\end{array}$ \\
\hline Mean & 3.8 & 38.6 & 7.5 & 6.2 & 37.4 & 7.3 & 2.7 & 25.4 & 7.4 & 3.4 & 48.2 & 12.3 \\
\hline
\end{tabular}

* TGFA = triglyceride fatty acid.

the normal range reported by Fredrickson and associates (13)..$^{3}$

All but two subjects demonstrated an increase in plasma triglyceride levels when their diet was changed from basal to fat free. This change was associated with the maintenance of grossly visible

3 One patient studied, a 25-year-old male, showed rapid clearing of lipemia on the fat-free regimen, very low levels of lipoprotein lipase ( $0.08 \mu \mathrm{Eq}$ per ml per minute), and normal glucose tolerance $(k=1.46)$, characteristics of "fat-induced" lipemia (4), and therefore was not included in the group. His plasma fat particle response to a fat load, although exaggerated and prolonged, was qualitatively similar to that previously described in normals (7). lipemia in all; however, one of the two turbid peaks usually observed in their lipemic plasma on fat-containing diets disappeared (Figure 1). The remaining fat particles on the fat-free regimen were electrophoretically homogeneous ("hyperlipemic particles"), but distinct from either type of fat particle observed in plasma of normals during alimentary lipemia (Table II). They migrated in the zone between beta and alpha globulin (migration distance, $0.51 \pm 0.07$; albumin $=1.00$ ), significantly different from either normal primary particles $(p<0.05)$ or secondary particles $(p<0.001)$. In PVP columns, however, they produced a broad hazy zone above the

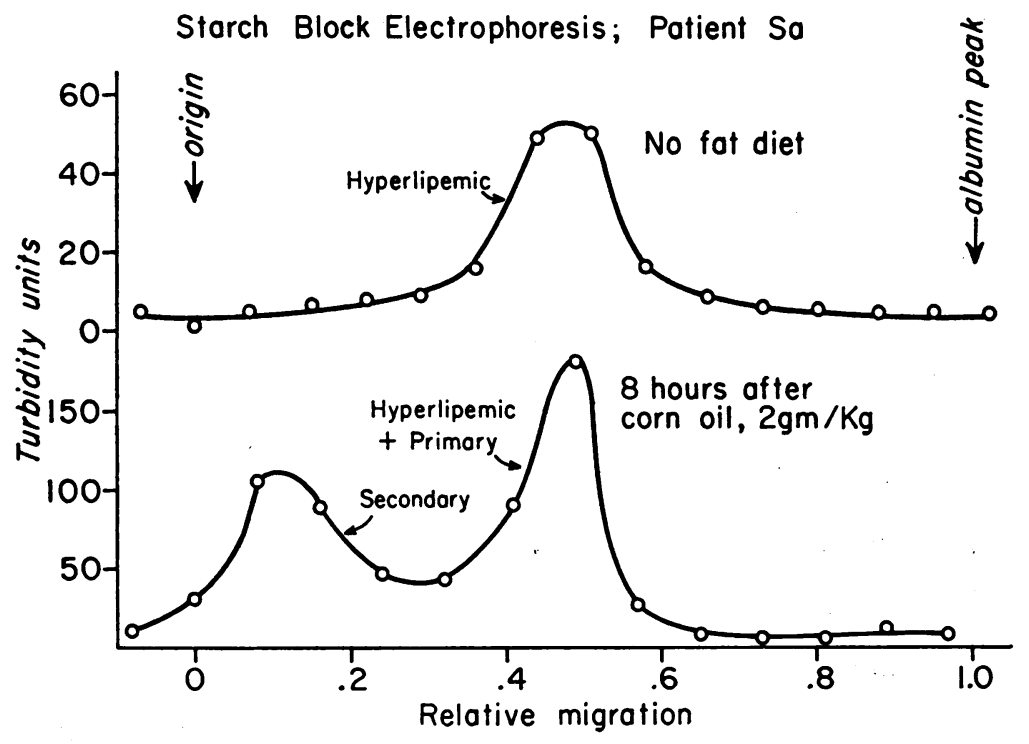

Fig. 2. Starch block electrophoresis of plasma of patient Sa on A FAT-FREE DIET AND 8 HOURS AFTER THE INGESTION OF CORN OIL, 2 G PER KG. 
TABLE IV

Linoleic: oleic acid ratios in particulate TGFA; fat-free diet followed by corn oil ingestion

\begin{tabular}{|c|c|c|c|c|c|c|c|}
\hline \multirow[b]{3}{*}{ Patient } & \multirow{3}{*}{$\begin{array}{c}\text { Peak tur- } \\
\text { bidity } \\
\text { Hours } \\
\text { after } \\
\text { fat load }\end{array}$} & \multicolumn{6}{|c|}{ Linoleic acid:oleic acid ratio } \\
\hline & & \multicolumn{2}{|c|}{ Hyperlipemic particles } & \multicolumn{2}{|c|}{ Alimentary particles } & \multirow{2}{*}{$\begin{array}{c}\text { Corn } \\
\text { oil } \\
\text { formula }\end{array}$} & \multirow[b]{2}{*}{$\begin{array}{l}\text { Adipose } \\
\text { tissue }\end{array}$} \\
\hline & & $\begin{array}{c}\text { Fat-free } \\
\text { diet* }\end{array}$ & 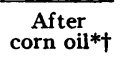 & Primary $\ddagger$ & Secondary* & & \\
\hline Ok & 24 & 0.23 & 0.50 & 1.46 & 0.87 & 1.81 & 0.21 \\
\hline $\mathrm{Sa}$ & 24 & 0.15 & 0.81 & 1.11 & 0.98 & 1.45 & \\
\hline Se & 12 & 0.08 & 0.98 & 1.42 & & 2.03 & 0.21 \\
\hline $\mathrm{Ra}$ & 12 & 0.27 & 1.02 & 1.52 & & 2.03 & 0.42 \\
\hline $\mathrm{Ja}$ & 5 & 0.22 & 0.43 & 1.46 & & 1.98 & 0.16 \\
\hline $\mathrm{Di}$ & 12 & 0.28 & 0.93 & 1.63 & 1.33 & 1.75 & 0.36 \\
\hline Pea & 8 & 0.11 & 0.58 & 1.62 & & 1.75 & 0.21 \\
\hline $\mathrm{Al}$ & 8 & 0.23 & 1.72 & & 1.08 & 2.19 & 0.20 \\
\hline
\end{tabular}

* Isolated by electrophoresis.

$\dagger$ Mixture of primary and hyperlipemic particles in all except Ok.

¥ Isolated by polyvinylpyrrolidone (PVP) in all except $\mathrm{Ok}$.

plasma layer and opalescence of the entire tube. When isolated electrophoretically, these hyperlipemic particles were rich in cholesterol content, $20 \pm 4 \%$ by weight, when compared to normal primary or secondary particles ( 7 to $8 \%, \mathrm{p}<$ 0.001 ). Approximately two-thirds of the sterol was esterified. Phospholipid content was also elevated $(p<0.01)$. Reciprocally, triglyceride content was diminished. Particle TGFA composition differed from adipose tissue, since the proportion of palmitic acid $(16: 0)$ and stearic acid $(18: 0)$ was consistently increased whereas oleic acid $(18: 1)$ and linoleic acid $(18: 2)$ decreased ( $p<0.01$, paired comparisons) (Table III). Adipose tissue TGFA composition in these subjects resembled that reported for normals (25, $27,28)$.

After a fat load, a single peak was no longer apparent on starch block electrophoresis. Two distinct peaks appeared. One of these was indistinguishable from secondary particles observed during alimentary lipemia in normal subjects. The other appeared to be a mixture of primary and hyperlipemic particles and could not be separated by this means (Figure 2 ). ${ }^{4}$ However, on PVP columns, primary particles typically flocculated at the top and could be readily isolated. Hyperlipemic particles remained as a diffuse opalescence concentrated at the lower portion of the tube. Thus, by both methods, the three types

4 Separation of primary and hyperlipemic particles by electrophoresis was possible in one instance $(\mathrm{Ok})$, and data obtained as a result of this separation are included in Table IV. of particle observed in this study were identified and separated.

As observed previously (7) the linoleic acid: oleic acid ratio of TGFA in primary particles, isolated by PVP fractionation, closely resembled the fed fat (Table IV). The TGFA pattern in secondary particles, isolated by electrophoresis, showed greater differences from the corn oil pattern. Since the turbid peak in the alpha 2 region contained both hyperlipemic and primary particles, the imprint of dietary TGFA on hyperlipemic particles was difficult to evaluate.

A comparison of the lipid composition of particles isolated from the alpha 2 region on electrophoresis to primary particles separated from the same sample on PVP columns reflects this mixing (Table V). The cholesterol content of

TABLE V

Cholesterol content of particles on fat-free diet and at maximal lipemia after corn oil feeding

\begin{tabular}{|c|c|c|c|}
\hline \multirow[b]{3}{*}{ Patient } & \multicolumn{3}{|c|}{ Cholesterol } \\
\hline & \multicolumn{2}{|c|}{$\begin{array}{c}\text { Hyperlipemic } \\
\text { particles* }\end{array}$} & \multirow{2}{*}{$\begin{array}{l}\text { Primary } \\
\text { particlest } \\
\text { After } \\
\text { fat }\end{array}$} \\
\hline & $\overline{\begin{array}{c}\text { Fat-free } \\
\text { diet }\end{array}}$ & $\begin{array}{c}\text { After } \\
\text { fat }\end{array}$ & \\
\hline & \multicolumn{3}{|c|}{$\%$ total lipid } \\
\hline $\begin{array}{l}\mathrm{Sa} \\
\mathrm{Se} \\
\mathrm{Ra} \\
\mathrm{Di}(1) \\
\quad(2) \ddagger \\
\mathrm{Pea} \\
\mathrm{Al}\end{array}$ & $\begin{array}{l}14.8 \\
14.5 \\
18.0 \\
26.0 \\
21.4 \\
18.7 \\
15.0\end{array}$ & $\begin{array}{c}8.3 \\
9.0 \\
10.3 \\
14.0 \\
12.3 \ddagger \\
13.6 \\
7.8\end{array}$ & $\begin{array}{c}10.6 \\
6.3 \\
5.6 \\
9.1 \\
5.4 \ddagger \\
7.3\end{array}$ \\
\hline
\end{tabular}

* Electrophoretic isolation from alpha 2 region.

+ PVP isolation.

$\ddagger$ Butter fat instead of corn oil. 


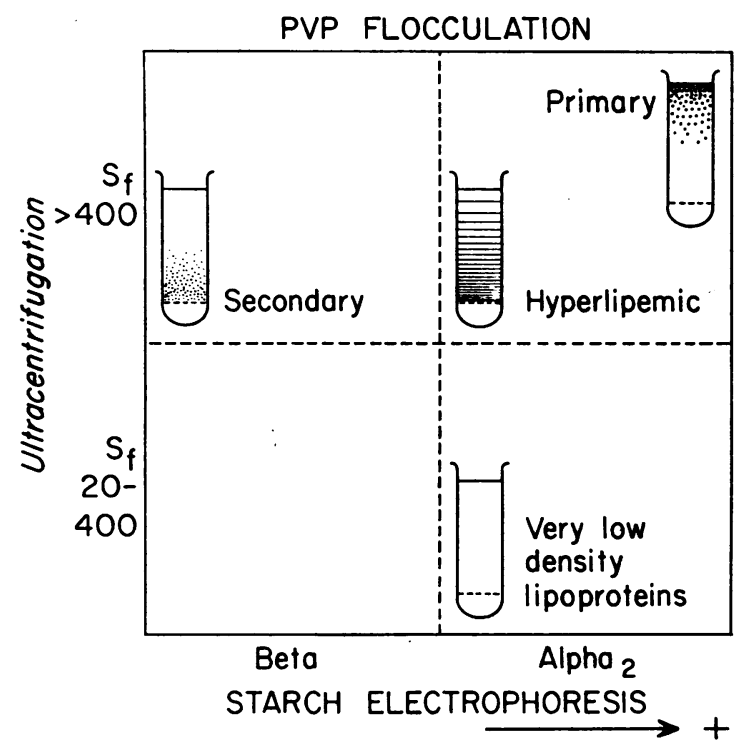

Fig. 3. Diagrammatic Representation of the RELATIONSHIP AMONG PRIMARY PARTICLES, SECONDARY PARTICLES, HYPERLIPEMIC PARTICLES, AND VERY LOW DENSITY LIPOPROTEINS, AS DETERMINED FROM ULTRACENTRIFUGAL, ELECTROPHORETIC, AND FLOCCULATION DATA.

the particles in the alpha 2 region decreased in all studies after fat ingestion $(p<0.001$, paired comparisons), but remained above that found in primary particles. Cholesterol in primary particles of these patients, isolated by PVP separation $(7 \pm 2 \%)$, was similar to that previously observed in normal subjects $(8 \pm 3 \%, \mathrm{p}>0.70)$. A summary of the relationship among primary, secondary, and hyperlipemic particles, as deter- mined from ultracentrifugal, electrophoretic, and flocculation data, is depicted in Figure 3 and Table 6.

\section{Discussion}

The group of hyperlipemic subjects comprising the present study is similar to the "carbohydrate-induced" lipemic patients described by Ahrens and colleagues $(4,5)$. In general accord with their observations, these patients had grossly visible lipemia on moderate fat intakes, and this lipemia usually increased after a change to a fat-free, high-carbohydrate diet. In addition, they had normal postheparin plasma lipoprotein lipase levels and manifested some degree of carbohydrate intolerance (6). The group differs in that most of the patients included in this study had abnormal responses to oral and intravenous carbohydrate loads, and several had abnormal fasting blood glucose levels. Since none of these patients had insulin-dependent diabetes, no further subdivision of the group based on the severity of carbohydrate intolerance was made. They appear to be similar to patients with "idiopathic hyperlipemia" and mild diabetes previously described (30-34).

On fat-containing diets, a heterogeneous mixture of fat particles accumulated in postabsorptive plasma of these hyperlipemic subjects, consistent with earlier observations of Swahn (9) and Carlson and Olhagen (10). When fat was eliminated from the diet, particles of alimentary

TABLE VI

Properties of fat particles and very low density lipoproteins

\begin{tabular}{|c|c|c|c|c|}
\hline & $\begin{array}{l}\text { Primary } \\
\text { particles }\end{array}$ & $\begin{array}{l}\text { Secondary } \\
\text { particles }\end{array}$ & $\begin{array}{c}\text { Hyperlipemic } \\
\text { particles }\end{array}$ & $\begin{array}{l}\text { Very low density } \\
\text { lipoproteins }\end{array}$ \\
\hline $\begin{array}{l}\text { Ultracentrifugal flotation; } \\
\text { calculated } S_{f}\end{array}$ & $>400$ & $>400$ & $>400$ & $20-400$ \\
\hline $\begin{array}{l}\text { Electrophoretic mobility } \\
\quad(\text { Albumin }=1.00)\end{array}$ & $\begin{array}{c}.60 \\
\left(\text { Alpha }_{2}\right)\end{array}$ & (Beta) & $\begin{array}{c}.51 \\
\left(\text { Alpha }_{2} \text {-beta) }\right.\end{array}$ & $\left(\text { Alpha }_{2}\right)^{.57}$ \\
\hline PVP flocculation & Top & Bottom & $\begin{array}{l}\text { Diffuse spread } \\
\text { from bottom }\end{array}$ & $\begin{array}{l}\text { None-bottom } \\
\text { (Concentration } \\
\text { dependent) }\end{array}$ \\
\hline \multicolumn{5}{|l|}{ Lipid composition, \% by wt } \\
\hline $\begin{array}{l}\text { Total cholesterol* } \\
\text { Phospholipid } \\
\text { Triglyceride }\end{array}$ & $\begin{array}{r}8 \\
6 \\
86\end{array}$ & $\begin{array}{r}7 \\
3 \\
90\end{array}$ & $\begin{array}{l}20 \\
10 \\
70\end{array}$ & $\begin{array}{l}32 \dagger \\
18 \\
50\end{array}$ \\
\hline Protein composition, \% by wt & 1 & 1 & 3 & $9 \dagger$ \\
\hline
\end{tabular}

* Sterol $\times 1.5$.

† Calculated from data compiled by Oncley (29). 
origin disappeared from plasma, revealing a single homogeneous group of particles. Plasma triglyceride levels increased after this dietary shift in most, but not all, patients in this study. Presumably, the highly variable accumulation of alimentary fat particles that preceded the institution of the fat-free diet influenced the direction and magnitude of change in plasma triglyceride concentration.

The hyperlipemic particles, persisting after the elimination of dietary fat, differ from particles isolated during alimentary lipemia in both normal subjects and the patients in the present study. First, they contain more than twice as much cholesterol as do primary or secondary particles. The cholesterol-rich, lowest density lipoprotein fraction reported in patients with elevated plasma triglyceride levels on mixed diets presumably reflects the presence of hyperlipemic particles (3540). Large concentration of particles such as these, rich in both cholesterol and triglyceride, could account for the correlation reported by Albrink (37) between the degree of hyperlipemia and the proportion of total plasma cholesterol present in the particulate fraction. Second, their electrophoretic behavior differs from that of other particles, since they migrate faster than secondary particles and slightly slower than primary particles. However, they are operationally difficult to separate from primary particles by electrophoresis alone. Third, although they interact with PVP, they do not form discrete, visible aggregates as do primary or secondary particles. Rather, they produce a dense bluish opalescence that is concentrated above the plasma layer but extends in diminished concentration to the top of the tube. Finally, their TGFA pattern is distinctly different from adipose tissue triglyceride. In accord with observations of Ahrens and Spritz (5), they were found to contain a high proportion of saturated fatty acids, suggesting that they are derived from hepatic lipogenesis (41).

Hyperlipemic particles and fat particles isolated during alimentary lipemia are similar only in that they form turbid solutions at room temperature and readily float with centrifugation $\left(10^{6} \mathrm{~g}\right.$ $\times$ minutes in an angle rotor; $S_{f}>400$ ) in saline $(\mathrm{D}<1.006)$. Thus, they are difficult to fractionate by ultracentrifugation alone.
After fat ingestion, apparently typical primary and secondary particles may appear in plasma of these subjects and readily accumulate. They reach a higher peak level at a later time and persist longer in plasma than in normal subjects ingesting similar fat loads (7). Presumably, this is related to a rate-limiting, common removal mechanism for all types of particulate triglyceride, since Nestel has reported greater accumulation of triglyceride during alimentary lipemia in plasma from patients with initially elevated circulating triglyceride levels (42). Therefore, in hyperlipemics ingesting mixed diets, a complex array of fat particles may be present in plasma. For example, dietary fat may accumulate in primary particles even though a basic abnormality of hyperlipemic particle turnover exists, resulting in the mixture observed in this and other studies $(9,10,43)$.

Thus, combined evidence indicates that the broad class of lowest density lipoproteins (density less than $1.006, S_{\mathrm{f}} 20$ to $10^{5}$ ) is heterogeneous. They can be fractionated into three distinct groups after fat ingestion in normal subjects, and a fourth in many hyperlipemic subjects by a combination of methods including zone electrophoresis on nonadsorptive media, ultracentrifugation, and PVP flocculation (Figure 3).

Specifically, alpha 2 lipoproteins, delineated by Kunkel and Trautman (15), are present normally in small quantities in postabsorptive plasma and have flotation rates in the $S_{f} 20$ to 400 range. Primary particles also migrate in the alpha $_{2}$ globulin region. They can be distinguished by their turbidity in solution at room temperature and can be separated either by brief ultracentrifugation in saline or PVP flocculation. Secondary particles, on the other hand, migrate in the $\beta$-globulin region and can be readily isolated after electrophoresis from denser $\beta$-lipoproteins $\left(S_{t} 0\right.$ to 20$)$ by centrifugation in saline. Hyperlipemic particles closely resemble alpha 2 lipoproteins $\left(S_{f} 20\right.$ to 400$)$, with the methods employed, except with regard to flotation rate. Possibly, they are derived from alpha 2 lipoproteins simply by the addition of excess triglyceride formed in the liver as a result of enhanced lipogenesis, presumed to be a characteristic of carbohydrate-dependent lipemia (44). 


\section{Summary}

In plasma of hyperlipemic subjects on ordinary diets, a mixture of fat particles can be found with properties similar to primary and secondary particles observed in normal subjects during alimentary lipemia. However, when fat is excluded from the diet for prolonged periods, plasma from patients who maintain gross hyperlipemia contains only one type of particle distinctly different from those recovered following fat ingestion. This "hyperlipemic" particle is unusually rich in cholesterol and, although grossly visible $\left(S_{t}>400\right)$, resembles very low density lipoproteins $\left(S_{f} 20\right.$ to 400$)$ more closely than other lipidprotein aggregates. Fat particle mixtures in plasma can be fractionated by a combination of methods, including zone electrophoresis on nonadsorptive media, ultracentrifugation, and polyvinylpyrrolidone flocculation.

\section{Acknowledgments}

The authors are grateful to Drs. E. H. Ahrens, Jr., and J. W. Farquhar for making plasma samples available for analysis from their patients undergoing similar dietary studies, and to Dr. D. S. Fredrickson for several of the lipoprotein lipase analyses. The authors are also indebted to Dr. R. H. Williams for his continued interest and support. The skilled technical assistance of Seniye Temel, Shirley Bishop, and Eileen Severns is appreciated.

\section{References}

1. Dole, V. P., E. Gordis, and E. L. Bierman. Current concepts in therapy. Hyperlipemia and arteriosclerosis. New Engl. J. Med. 1963, 269, 686.

2. Dole, V. P., and J. T. Hamlin III. Particulate fat in lymph and blood. Physiol. Rev. 1962, 42, 674.

3. Fredrickson, D. S. Essential familial hyperlipidemia in The Metabolic Basis of Inherited Disease, J. B. Stanbury, J. B. Wyngaarden, and D. S. Fredrickson, Eds. New York, McGraw-Hill, 1960, p. 489.

4. Ahrens, E. H., Jr., J. Hirsch, K. Oette, J. W. Farquhar, and Y. Stein. Carbohydrate-induced and fat-induced lipemia. Trans. Ass. Amer. Phycns 1961, 74, 134.

5. Ahrens, E. H., Jr., and N. Spritz. Further studies on fat- and carbohydrate-induced lipemia in man. Reduction of lipemia by feeding fat in Biochemical Problems of Lipids, A. C. Frazer, Ed. New York, Elsevier, 1963, p. 304.

6. Knittle, J. L., and E. H. Ahrens, Jr. Carbohydrate metabolism in two forms of hyperglyceridemia. J. clin. Invest. 1964, 43, 485.
7. Bierman, E. L., E. Gordis, and J. T. Hamlin III. Heterogeneity of fat particles in plasma during alimentary lipemia. J. clin. Invest. 1962, 41, 2254.

8. Gordis, E. Demonstration of two kinds of fat particles in alimentary lipemia with polyvinylpyrrolidone gradient columns. Proc. Soc. exp. Biol. (N. Y.) 1962, 110, 657.

9. Swahn, B. Studies on blood lipids. Scand. J. clin. Lab. Invest. 1953, 5 (suppl. 9).

10. Carlson, L. A., and B. Olhagen. Electrophoretic mobility of chylomicrons in a case of essential hyperlipemia. Scand. J. clin. Lab. Invest. 1954, 6, 70.

11. Saifer, A., and S. Gerstenfeld. The photometric microdetermination of blood glucose with glucose oxidase. J. Lab. clin. Med. 1958, 51, 448.

12. Hoffman, W. S. Rapid photoelectric method for the determination of glucose in blood and urine. J. biol. Chem. 1937, 120, 51.

13. Fredrickson, D. S., K. Ono, and L. L. Davis. Lipolytic activity of post-heparin plasma in hyperglyceridemia. J. Lipid Res. 1963, 4, 24.

14. Bierman, E. L., and J. T. Hamlin III. The hyperlipemic effect of a low-fat, high-carbohydrate diet in diabetic subjects. Diabetes 1961, 10, 432.

15. Kunkel, H. G., and R. Trautman. The $\alpha_{2}$ lipoproteins of human serum. Correlation of ultracentrifugal and electrophoretic properties. J. clin. Invest. $1956,35,641$.

16. Lowry, O. H., N. J. Rosebrough, A. L. Farr, and R. J. Randall. Protein measurement with the Folin phenol reagent. J. biol. Chem. 1951, 193, 265.

17. Youden, W. J. Statistical Methods for Chemists. New York, John Wiley, 1951, p. 16.

18. Laurell, S. The effect of free fatty acids on the migration rates of lipoproteins in paper electrophoresis. Scand. J. clin. Lab. Invest. 1955, 7, 28.

19. Searcy, R. L., L. M. Bergquist, and R. C. Jung. Rapid ultramicro estimation of serum total cholesterol. J. Lipid Res. 1960, 1, 349.

20. Amenta, J. S. A rapid chemical method for quantification of lipids separated by thin-layer chromatography. J. Lipid Res. 1964, 5, 270.

21. Bartlett, G. R. Phosphorus assay in column chromatography. J. biol. Chem. 1959, 234, 466.

22. Dole, V. P., and H. Meinertz. Microdetermination of long-chain fatty acids in plasma and tissues. J. biol. Chem. 1960, 235, 2595.

23. O'Hara, D. D., D. Porte, Jr., and R. H. Williams. Unpublished data.

24. Dole, V. P., A. T. James, J. P. W. Webb, M. A. Rizack, and M. F. Sturman. The fatty acid patterns of plasma lipids during alimentary lipemia. J. clin. Invest. 1959, 38, 1544.

25. Hirsch, J., J. W. Farquhar, E. H. Ahrens, Jr., M. L. Peterson, and W. Stoffel. Studies of adipose tissue in man. A microtechnic for sampling and analysis. Amer. J. clin. Nutr. 1960, 8, 499. 
26. Amaral, J. A. P., F. C. Wood, Jr., and E. L. Bierman. Unpublished data.

27. Lee, K. T., R. F. Scott, E. S. Morrison, and W. A. Thomas. Chemico-anatomic studies of arteriosclerosis and thrombosis in diabetics. II. Fatty acids of adipose tissue and plasma lipids in several groups of North American diabetics and nondiabetics. Exp. molec. Path. 1962, 1, 364.

28. Krut, L. H., and B. Bronte-Stewart. The fatty acids of human depot fat. J. Lipid Res. 1964, 5, 343.

29. Oncley, J. L. The lipoproteins of human plasma in The Lipoproteins. Methods and Clinical Significance, F. Homburger and P. Bernfeld, Eds. New York, S. Karger, 1958, p. 14.

30. Adlersberg, G. D., and C. I. Wang. Syndrome of idiopathic hyperlipemia, mild diabetes mellitus and severe vascular disease. Diabetes 1955, 4, 210.

31. Waddell, W. R., R. P. Geyer, N. Hurley, and F. J. Stare. Abnormal carbohydrate metabolism in patients with hypercholesterolemia and hyperlipemia. Metabolism 1958, 7, 707.

32. Christensen, S., E. Dollerup, and S. E. Jensen. Idiopathic hyperlipaemia, latent diabetes mellitus and severe neuropathy. Acta med. scand. 1958, 161, 57.

33. Carlson, L. A., and B. Olhagen. Studies on a case of essential hyperlipemia. Blood lipids, with special reference to the composition and metabolism of the serum glycerides before, during and after the course of a viral hepatitis. J. clin. Invest. 1959, $38,854$.

34. Crofford, O. B. Studies on the mechanism of idiopathic hyperlipemia with hyperglycemia. Metabolism 1962, 11, 1194.
35. Schettler, G., M. Eggstein, and H. Jobst. Essential hyperlipaemia. Germ. med. Mth. 1958, 3, 310.

36. Havel, R. J., and R. S. Gordon, Jr. Idiopathic hyperlipemia : metabolic studies in an affected family. J. clin. Invest. 1960, 39, 1777.

37. Albrink, M. J. Lipoprotein pattern as a function of total triglyceride concentration of serum. J. clin. Invest. 1961, 40, 536.

38. Forbes, J. C., P. D. Camp, A. J. Wasserman, W. T. Tucker, A. L. Forbes, and O. M. Petterson. Effect of centrifugation at $20,000 \times g$ on lipid distribution of human sera. Proc. Soc. exp. Biol. (N. Y.) 1961, 107, 224.

39. Furman, R. H., R. P. Howard, K. Lakshmi, and L. N. Norcia. The serum lipids and lipoproteins in normal and hyperlipidemic subjects as determined by preparative ultracentrifugation. Amer. J. clin. Nutr. 1961, 9, 73.

40. Angervall, G., P. Björntorp, and B. Hood. Studies on the clearing phenomenon in essential hyperlipemia. Acta med. scand. 1962, 172, 5.

41. Evans, J. D., and L. N. Norcia. Incorporation of acetate- $\mathrm{C}^{14}$ into individual fatty acids of rat liver triglycerides and phospholipids. J. Lipid Res. 1964, 5, 395.

42. Nestel, P. J. Relationship between plasma triglycerides and removal of chylomicrons. J. clin. Invest. 1964, 43, 943.

43. Nye, W. H. R. An assessment of the role of alpha and beta chylomicra in hyperlipemic states. Proc. Soc. exp. Biol. ( N.Y.) 1964, 116, 350.

44. Farquhar, J. W., G. M. Reaven, R. Gross, and R. Wagner. Rate of plasma triglyceride synthesis in carbohydrate-induced lipemia (abstract). J. clin. Invest. 1963, 42, 930. 